\title{
Pelaksanaan Pendidikan Transformatif dalam Menghasilkan Pendidik Matematika yang Islami, Profesional, dan Kompetitif
}

\author{
Dini Palupi Putri ${ }^{1}$, Fitmawati \\ ${ }^{1}$ Institut Agama Islam Negeri Curup \\ 1dinigusnadi@gmail.com
}

\begin{tabular}{l}
\hline \hline Article Info \\
\hline Article history: \\
Received Nov $11^{\text {th }} 2021$ \\
Revised Nov $23^{\text {th }} 2021$ \\
Accepted Nov $28^{\text {th }} 2021$ \\
\hline
\end{tabular}

\section{Keywords:}

Transformative

Education;

Islamic;

Professional;

Competitive

\section{Abstract}

This study aims to analyze the implementation of transformative education in the Mathematics Education (Tadris Matematika) Study Program in producing Islamic, professional, and competitive mathematics educators. The sample in this research is Mathematics Education (Tadris Matematika) lecturers and students. Collecting data using observation, interviews, and documentation. The methods of data analysis used are reduction, display, and conclusion drawing and triangulation techniques. From this study, it was found that the implementation of transformative education in mathematics education (tadris matematika) study program was carried out by lecturers in producing Islamic, professional, and competitive mathematics educators. In producing Islamic educators, it is necessary to evaluate and improve again. In producing professional educators, the effort is still minimal, while the efforts of lecturers in producing competitive mathematics educators already exist through scientific writing competitions, but this has not had a good impact on producing competitive mathematics educators because most students are still insecure/lack of confidence in take part in competitions. The obstacles found are the lack of supporting infrastructure in professional development and the lack of self-confidence and motivation from students and lecturers. The contribution in this research is as an evaluation material for Mathematics Education (Tadris Matematika) lecturers, faculties in improving prospective Islamic, professional, and competitive mathematics educators in accordance with the vision and mission of the Mathematics Education (Tadris Matematika). 
Kata Kunci:

Pendidikan

Transformatif;

Islami;

Profesional;

Kompetitif
Tujuan penelitian ini adalah untuk menganalisis pelaksanaan pendidikan transformatif di Program Studi Tadris Matematika dalam menghasilkan pendidik matematika yang islami, profesional, dan kompetitif. Sampel dalam penelitian ini adalah dosen dan mahasiswa Program Studi Tadris Matematika IAIN Curup. Pengumpulan data mengunakan observasi, wawancara dan dokumentasi. Metode dalam analisis data yang digunakan adalah reduksi, display dan conclusion drawing serta teknik triangulasi. Dari penelitian ini didapatkan bahwa untuk menghasilkan pendidik yang Islami perlu adanya evaluasi dan peningkatan lagi. Dalam menghasilkan pendidik yang profesional usaha masih minim sedangkan usaha dosen dalam menghasilkan pendidik matematika yang kompetitif sudah ada melalui ajang-ajang lomba penulisan karya ilmiah, namun hal ini belum berdampak baik dalam menghasilkan pendidik matematika yang kompetitif karena kebanyakan mahasiswa masih minder/kurang percaya diri dalam mengikuti ajang-ajang perlombaan. Hambatan yang ditemukan adalah kurangnya saranaprasarana yang mendukung dalam pengembangan profesional dan kurangnya percaya diri dan motivasi dari dalam diri mahasiwa dan dosen. Kontribusi dalam peneltian ini adalah sebagai bahan evaluasi untuk para dosen tadris matematika, fakultas dalam peningkatan calon pendidik matematika yang Islami, profesional, dan kompetitif sesuai dengan Visi Misi Prodi Tadris Matematika.

\section{PENDAHULUAN}

Peran perguruan tinggi sangat penting dalam roda penggerak perubahan bangsa dan sebagai penggagas-penggagas ide baru guna mencari terobosan baru maupun penggagas pemecahan permasalah bangsa yang sedang dihadapi (Kartasasmita, 2004). Perkembangan IPTEK yang pesat terutama di bidang teknologi informasi yang mempercepat proses globalisasi dikhawatirkan juga dapat membawa dampak negatif terhadap nilai-nilai pendidikan dan pakar-pakar ilmu sosial umumnya ditantang untuk dapat melakukan pengkajian dan pengajaran di perguruan tinggi sehingga generasi muda kita mempunyai 
daya tangkap yang tangguh terhadap nilai-nilai baru yang negatif. Peran perguruan tinggi sangat penting guna meminimalisir dampak buruk penyalahgunaan perkembangan IPTEK yang sangat pesat pada era global ini.

Tujuan pendidikan tinggi menurut Peraturan Pemerintah RI Nomor 60 Tahun 1999 dalam (Syukron, 2016) adalah sebagai untuk Pertama, menyiapkan peserta didik menjadi anggota masyarakat yang memiliki kemampuan akademik dan atau profesional yang dapat menerapkan, mengembangkan dan atau memperkaya khasanah ilmu pengetahuan, teknologi dan atau kesenian. Kedua, mengembangkan dan menyebarluaskan ilmu pengetahuan, teknologi, dan atau kesenian serta mengupayakan penggunaannya untuk meningkatkan taraf kehidupan masyarakat dan memperkaya kebudayaan nasional.

Tujuan pendidikan tinggi yang disebutkan di atas mengamanahkan beberapa kewajiban kepada dosen sebagai roda penggerak pendidikan di perguruan tinggi. Dosen tidak hanya mengarahkan peserta didik untuk baik dalam kognitif, tapi juga baik dalam segi afektif dan psikomotorik, serta melatih peserta didik agar dapat menyelesaikan masalah apabila terjun ke lapangan sesuai bidang yang telah mereka geluti (Taufiq, 2018). Keberhasilan tujuan pendidikan dan proses pembelajaran yang berlangsung pada pendidikan tinggi seyogyanya dosen bukan lagi menjadi fokus pembelajaran, namun sebaliknya, mahasiswa memiliki posisi yang sangat signifikan bagi keberhasilan proses pembelajaran.

Program studi sebagai bagian dari perguruan tinggi juga mempunyai peran yang sangat penting dalam mengembangkan ilmu pengetahuan dan karakter bangsa. Mahasiswa lulusan program studi pendidikan tidak hanya dituntut mahir dalam mengaplikasikan teknologi dalam pembelajaran, tetapi juga harus berkarakter dan kompetitif. Pendidik yang berkarakter akan menjadi teladan bagi anak didiknya dan dapat meningkatkan pengembangan karakter yang baik bagi anak didik. Sejalan dengan Maunah (Binti, 2016), pembentukan karakter anak didik dapat dilakukan dengan dua strategi, yaitu strategi di dalam tempat anak belajar, dan strategi di luar tempat anak belajar. Selain itu, pendidik juga harus dituntut kompetitif, mengikuti ajang-ajang kompetisi untuk 
mengasah keterampilannya dan sebagai bahan evaluasi diri akan kekurangan yang dimilkinya.

Program Studi Tadris Matematika merupakan program studi yang baru berdiri 3 tahun di IAIN Curup. Meskipun baru di institusi IAIN Curup, program studi tadris matematika banyak melakukan gebrakangebrakan baru dan perubahan-perubahan ke arah yang lebih baik. Gebrakan-gebrakan tersebut bisa dilihat dari proses perkuliahan di kelas, sarana dan prasarana, peningkatan mutu dosen, keikutsertaan dalam ajang perlombaan-perlombaan ilmiah, keikutsertaan dalam seminar-seminar ilmiah baik dosen dan mahasiswa. Minat masyarakat menitipkan anaknya untuk menuntut ilmu di program studi tadris matematika juga sangat baik.

Jumlah mahasiswa program studi tadris matematika 3 Tahun berjalan adalah untuk angkatan pertama tahun 2017 sebanyak 17 mahasiswa, angkatan tahun 2018 sebanyak 35 mahasiswa, dan angkatan 2019 sebanyak 50 mahasiswa. Hal ini menunjukkan peningkatan minat dan kepercayaan masyarakat untuk menuntut ilmu di program studi tadris matematika. Peningkatan minat dan kepercayaan masyarakat belum maksimal untuk itu perlu pelaksanaan pendidikan transformatif, dimulai dari pelaksanaan sosialisasi di masyarakat, perekrutan mahasiswa baru, pelaksanaan perkuliahan, dan kelulusan mahasiswa. Sejalan dengan (Rinawati, 2015) yang menyatakan peran transformasi pendidikan terhadap globalisasi dapat dilakukan dengan menggunakan langkah pembaharuan di bidang pendidikan itu sendiri. Pembaharuan dilakukan di mulai dari sosialisasi, perekrutan, pelaksanaan perkuliahan sampai kelulusan mahasisswa guna menghasilkan lulusan pendidik yang islami, profesional, dan kompetitif.

Visi Program Studi Tadris Matematika yaitu Menjadi Program Studi Bermutu dan Terkemuka dalam Menghasilkan Pendidik Matematika yang Islami, Profesional, dan Kompetitif pada Jenjang Pendidikan Menengah di Wilayah Sumatera. Dalam mewujudkan visi, program studi tadris matematika perlu bertransformasi ke arah yang lebih baik, guna mempertahankan esensi institusi di mata masyarakat, selain itu juga menguatkan kepercayaan masyarakat bahwa lulusan program studi tadris matematika nantinya mampu bersaing di tingkat lokal, nasional, 
maupun internasional. Pelaku pendidikan transformasi ialah dosen-dosen, mahasiswa, dan lingkungan sekitar.

Dari latar belakang tersebut maka rumusan permasalahan dalam penelitian ini yaitu bagaimana pelaksanaan pendidikan transformatif di program studi tadris matematika di IAIN Curup yang dilakukan dosen dalam menghasilkan pendidik matematika yang islami, profesional, dan kompetitif dan apa saja hambatan dalam pelaksanaan pendidikan transformatif di program studi tadris matematika di IAIN Curup dalam menghasilkan pendidik matematika yang islami, profesional, dan kompetitif. Maka tujuan dalam penelitian ini untuk mengetahui pelaksanaan pendidikan transformatif di program studi tadris matematika di IAIN Curup yang dilakukan dosen dalam menghasilkan pendidik matematika yang islami, profesional, dan kompetitif serta hambatan dalam pelaksanaannya untuk menghasilkan pendidik matematika yang islami, profesional, dan kompetitif.

\section{METODE PENELITIAN}

\section{Ruang Lingkup Penelitian}

Penelitian ini merupakan penelitian deskriptif kualitatif. Dalam penelitian ini akan dideskripsikan bagaimana pelaksanaan pendidikan transformatif, peran dosen dan mahasiswa program studi tadris matematika dalam mewujudkan pendidik yang islami, profesional, dan kompetitif serta akan dilihat juga hambatan-hambatan yang dialami dosen dan mahasiswa dalam usaha melakukan pelaksanaan pendidikan transformatif di program studi tadris matematika.

\section{Jenis Pengumpulan Data}

Pengumpulan data yang digunakan dalam penelitian ini adalah observasi, wawancara, dan dokumentasi. Observasi digunakan untuk melihat benar tidaknya antara hasil wawancara dengan apa yang terjadi di lapangan. Observasi yang digunakan adalah observasi non partisipan dimana observer tidak ikut terlibat dalam objek penelitian. Observasi dilakukan menggunakan lembar observasi guna melihat pelaksanaan pendidikan transformatif di program studi tadris matematika dalam 
menciptakan pendidik yang islami, profesional, dan kompetitif. Wawancara yang dilakukan dalam penelitian ini adalah wawancara terbuka. Dimana informan diberi kebebasan dalam menjawab pertanyaan. Wawancara dilakukan kepada dosen dan mahasiswa tadris matematika. Wawancara bertujuan untuk mengungkapkan bagaimana pelaksanaan pendidikan transformatif yang sudah dilaksanakan oleh dosen dan mahasiswa tadris matematika. Pertanyaan wawancara didesain berdasarkan indikator-indikator yang relevan berkenaan dengan pendidik yang profesional, islami, dan kompetitif. Dokumentasi dalam penelitian ini adalah dokumen yang terkait untuk mendukung pelaksanaan penelitian, peraturan-peraturan, buku-buku dan lain sebagainya.

\section{Metode Analisis Data}

Data hasil instrumen penelitian diolah secara deskriptif dengan triangulasi teknik, sumber, dan waktu. Miles dan Huberman, (1992:16) mengemukakan bahwa aktivitas dalam analisis kualitatif dilakukan secara interaktif dan berlangsung secara terus menerus sampai tuntas. Aktivitas dalam analisis data, yaitu data reduksi; data tentang pelaksanaan pendidikan transformatif yang diperoleh dari lapangan jumlahnya cukup banyak, untuk itu maka data perlu dianalisis dan dicatat secara teliti dan rinci mengenai indikator-indikator yang didapatkan. Data yang diambil hanya data yang diperlukan untuk mengungkapkan pelaksanaan pendidikan transformatif di program studi tadris matematika, data yang tidak diperlukan dalam penelitian dibuang saja. Data display, setelah data tentang pelaksanaan pendidikan transformatif direduksi, maka langkah selanjutnya adalah menyajikan data pelaksanaan pendidikan transformatif. Data disajikan dalam bentuk teks naratif, bagan, dan hubungan antar indikator. Conclusion Drawing/Verification kesimpulan awal yang dikemukakan bukti-bukti yang kuat mendukung pada tahap pengumpulan data pelaksanaan pendidikan transformatif berikutnya. Tetapi apabila kesimpulan yang dikemukakan pada tahap awal, didukung oleh bukti-bukti yang valid dan konsisten saat peneliti kembali ke lapangan mengumpulkan data, maka kesimpulan yang dikemukakan merupakan kesimpulan yang kredibel. Dalam penelitian ini untuk 
memperoleh data yang valid dan kredibel, peneliti menggunakan teknik triangulasi sumber. Triangulasi sumber merupakan kegiatan mengecek ulang keabsahan data yang diperoleh melalui sumber yang berbeda. Kegiatan pengecekan sumber data yang berbeda sebagai berikut: 1)membandingkan data hasil observasi dengan hasil wawancara; 2) membandingkan jawaban wawancara dosen satu dengan dosen yang lainnya; 3)membandingkan hasil wawancara mahasiswa satu dengan mahasiswa lainnya; dan 4)membandingkan hasil wawancara dengan dokumentasi yang tersedia di program studi.

\section{HASIL PENELITIAN DAN PEMBAHASAN}

\section{Pelaksanaan Pendidikan Transformatif di Program Studi Tadris Matematika di IAIN Curup yang Dilakukan Dosen dalam Menghasilkan Pendidik Matematika yang Islami, Profesional, dan Kompetitif}

Seorang pendidik sangatlah mulia di mata Allah SWT, ini dikarenakan tugasnya yang selalu berdakwah dan pahala seorang pendidik tidak akan pernah terputus, selama ilmu yang ia transfer pada peserta didik diamalkan oleh peserta didik. Kedudukan orang yang berilmu sangatlah istimewa, orang berilmu juga ditinggikan derajatnya olah Allah SWT. Dalam Islam, sosok guru lebih strategis lagi karena di samping mengemban misi keilmuan, guru juga mengemban tugas suci, yaitu misi dakwah dan misi kenabian, yakni membimbing dan mengarahkan peserta didik ke arah moralitas yang lebih baik menuju jalan Allah SWT (Mohammad, 2008).

Proses pendidikan transformatif dalam mencapai lulusan calon pendidik yang islami sudah diupayakan program studi tadris matematika, ini bisa dilihat dari usaha-usaha yang telah dilakukan oleh dosen dan mahasiswa. Dosen sudah melaksanakan dan mengintegrasikan nilai-nilai islami dalam pembelajaran. Tujuannya agar lulusan program studi tadris matematika nantinya menjadi pendidik yang selalu menerapkan nilai-nilai islami dalam mentransfer ilmu dan menjadi teladan yang baik bagi peserta didiknya. 
Kerjasama antara dosen dan mahasiswa dalam menuju pendidikan transformatif sudah cukup baik, dilihat dari proses pelaksanaannya. Berikut peneliti sajikan hasil observasi dalam bentuk Tabel 1 di bawah ini:

Tabel 1. Hasil Observasi Pelaksanaan Pendidikan Transformatif yang Dilakukan Dosen dalam Menghasilkan Pendidik yang Islami

\begin{tabular}{cc}
\hline Indikator Pendidik yang Islami & Persentase \\
\hline Bertaqwa & $93 \%$ \\
\hline Uswatun Hasanah & $87 \%$ \\
\hline Berilmu & $75 \%$ \\
\hline Sehat Jasmani & $76 \%$ \\
\hline Berkelakuan Baik & $89 \%$ \\
\hline
\end{tabular}

Usaha dosen dalam mengembangkan karakter bertakwa kepada Allah SWT, dari tabel di atas masih dikategorikan belum maksimal, bila ditransformasikan ke dalam bentuk persentase, usaha dosen baru mencapai 93\%. Artinya usaha dosen belum maksimal, dan perlu dievaluasi dan ditingkatkan lagi agar memperoleh hasil yang maksimal.

Hambatan dalam usaha mengembangkan karakter islami pada diri mahasiswa adalah pengaruh lingkungan atau pergaulan mahasiswa ketika di luar kampus (Nuqul, 2008). Lingkungan fisik dan sosial akan mempengaruhi kinerja fisik dan psikis seseorang yang juga akan sangat berpengaruh terhadap perilaku di tempat tersebut, baik perilaku secara individual maupun secara sosial.

Lingkungan tempat tinggal mahasiswa juga berperan penting dalam menentukan pribadi mahasiswa untuk itu, harus ada kerjasama pemerintah setempat untuk menciptakan karakter islami pada diri mahasiswa. Dukungan yang bisa dilakukan pemerintah melalui penyediaan sarana dan prasarana, misalkan pemerintah menyediakan tempat untuk berkumpul dalam proses transfer ilmu agama oleh ustadustad yang ada di tempat tinggal mahasiswa.

Pada Tabel 1 terlihat pengembangan karakter berilmu yang masih sedikit persentasenya yang dilakukan oleh dosen. Dari hasil wawancara dan observasi didapat informasi bahwa mahasiswa sedikit sekali yang menyediakan waktu untuk menambah ilmu agama, ataupun belajar 
konsep-konsep dan teori yang akan dipelajari pada saat tatap muka, selain itu kemampuan literasi mahasiswa juga belum maksimal. Harus ada perubahan dan tindakan, untuk mengembangkan budaya kegiatan pengembangan literasi.

Usaha dosen dalam meningkatkan literasi mahasiswa bisa dilakukan dengan melakukan perjanjian di awal pertemuan, dosen menegaskan bahwa mahasiswa wajib membaca sumber-sumber dan rujukan dari materi yang akan dipelajari, dosen juga bisa mengecek kemampuan literasi mahasiswa dengan melakukan kuis di awal pertemuan tatap muka. Dengan begitu kegiatan mengembangkan literasi akan membudaya pada diri mahasiswa. Tjahjadarmawan (Deden, 2018) menyatakan bahwa agar mahasiswa terpacu membaca di awal perkuliahan dosen harus membuat kesepakatan dengan mahasiswa salah satu isi kesepakatan tersebut adalah di akhir perkuliahan akan tercipta produk literasi. Isi produk tersebut adalah kumpulan tulisan mahasiswa dan dosen mengenai berbagai tema.

Pembentukan calon pendidik yang profesional juga sangat penting dalam pendidikan transformatif, agar mahasiswa sebagai calon pendidik mampu bersaing di dunia kerja saat terjun ke lapangan nantinya. Ada empat alasan yang kuat yang mendorong pendidik untuk mengembangkan profesionalisme (1) hakikat pendidik sebagai sebuah profesi; (2) perkembangan IPTEKS yang pesat; (3) filosofi belajar sepanjang hayat; dan (4) Undang-undang Nomor 14 Tahun 2015 tentang guru dan dosen (Wardani, 2012).

Hasil wawancara pada salah satu dosen "Dalam perkuliahan saya selalu mengarahkan mahasiswa untuk berdisiplin, bertanggung jawab dan bersamangat dalam mengikuti perkuliahan. Pada materi yang disampaikan saya selalu mengintegrasikan nilai-nilai karakter yang islami, agar menjadi sebuah pembiasaan karakter. Di luar jam perkuliahan saya menyempatkan diri untuk ikut kegiatan sholat Dhuha rutin."

Dengan demikian dapat dapat disimpulkan bahwa sudah ada usahausaha yang dilakukan dosen, namun usaha tersebut belum maksimal, masih ada poin-poin yang harus dievaluasi untuk memaksimalkan kegiatan tersebut. Berikut peneliti sajikan hasil observasi, usaha dosen 
dalam mengembangkan dan mengupayakan calon pendidik yang profesional dalam bentuk Tabel 2:

Tabel 2. Hasil Observasi Pelaksanaan Pendidikan Transformatif yang Dilakukan Dosen dalam Menghasilkan Pendidik yang Profesional

\begin{tabular}{cc}
\hline Indikator Pendidik yang Islami & Persentase \\
\hline Pedagogik & $82 \%$ \\
\hline Profesional & $77 \%$ \\
\hline Sosial & $88 \%$ \\
\hline Kepriadian & $90 \%$ \\
\hline
\end{tabular}

Pada Tabel 2 terlihat usaha yang masih minim adalah usaha dalam mengembangkan kompetensi profesional mahasiswa program studi tadris matematika, dari hasil wawancara ini dikarenakan mahasiswa masih banyak materi dan konsep-konsep yang belum dikuasai oleh mahasiswa, dari hasil observasi mahasiswa sedikit sekali dalam usaha menambah literasi akan materi yang akan dipelajari. Dalam membuat tugas kuliah, mahasiswa terbiasa dengan budaya copy paste, sehingga perkuliahan dan materi yang didapat menjadi tidak bermakna.

Budaya literasi sangat penting untuk dikembangkan agar menambah wawasan mahasiswa sebagai modal peningkatan kompetensi profesional. Pengetahuan yang luas bisa didapatkan dengan kegiatan literasi, semakin banyak sumber-sumber konsep dan materi yang kita baca dan kita pahami, maka semakin luas wawasan kita. Kualitas suatu bangsa biasanya berjalan seiring dengan budaya literasi, faktor kualitas dipengaruhi oleh membaca yang dihasilkan dari temuan-temuan para kaum cerdik pandai yang terekam dalam tulisan yang menjadikan warisan literasi informasi yang sangat berguna bagi proses kehidupan sosial yang dinamis (Ane, 2015).

Program studi tadris matematika juga bercita-cita dalam menghasilkan calon pendidik yang kompetitif agar mengasah kemampuan mahasiswa melalui kegiatan dan ajang-ajang kompetisi. Berikut peneliti sajikan hasil observasi terhadap usaha-usaha dosen dalam mengembangkan potensi calon pendidik yang kompetitif. 


\section{Tabel 3. Hasil Observasi Pelaksanaan Pendidikan Transformatif yang Dilakukan Dosen dalam Menghasilkan Pendidik yang Kompetitif}

\begin{tabular}{cc}
\hline Indikator Pendidik yang Islami & Persentase \\
\hline Karya Ilmiah & $77 \%$ \\
\hline Media & $80 \%$ \\
\hline Easiswa & $78 \%$ \\
\hline
\end{tabular}

Ajang kompetisi karya ilmiah dilakukan guna menggali potensi diri mahasiswa dalam menuangkan ide-ide dan pemikiran mereka, dan menuangkan hasil penelitian dari pengalaman mereka semasa perkuliahan. Kegiatan ini sangat erat sekali dengan dengan aktifitas mereka pada saat kuliah, tentunya menemukan permasalahanpermasalahan yang harus diteliti dan dicari solusi dari permasalahan tersebut.

Dari hasil wawancara yang didapatkan kebanyakan mahasiswa minder dan enggan mengikuti ajang kompetensi karya ilmiah. Mahasiswa tidak percaya diri dengan kemampuan mereka dalam membuat karya ilmiah, selain itu kemampuan mahasiswa dalam menulis masih minim. Hal ini tentunya sangat penting untuk dievaluasi dan dikembangkan kemampuan mereka dalam menulis karya ilmiah.

Dosen bisa membuat pendekatan perkuliahan dengan cara berdiskusi agar mahasiswa bisa berkolaborasi dalam menyelesaikan masalah. Sehingga nantinya, mahasiswa akan sama-sama belajar mengenai pembuatan suatu karya ilmiah. Kegiatan menyusun karya ilmiah bisa ditingkatkan melalui strategi Problem Based Learning (PBL), dimana pada tahap pemecahan masalah dan penyusunan karya ilmiah mahasiswa dapat berkolaborasi dalam menyusun produk pembelajaran (Mujianto, Zubaidi, \& Suprapto, 2012). 
Pelaksanaan Pendidikan Transformatif di Program Studi Tadris Matematika di IAIN Curup yang Dilakukan Mahasiswa dalam Menghasilkan Pendidik Matematika yang Islami, Profesional, dan Kompetitif

Pelaksanaan pendidikan transformatif bukan hanya dilakukan oleh dosen program studi tadris matematika, tetapi mahasiswa program studi tadris matematika ikut terlibat dalam pelaksanaan pendidikan transformatif ini. Dimana usaha dosen dan mahasiswa saling berkaitan dangan hasil. Maksimal atau belum maksimalnya pelaksanaan pendidikan transformatif ini.

Mahasiswa sebagai calon pendidik perlu mengembangkan karakter islami pada diri, dan membisakan diri dengan aktifitas-aktifitas yang bermanfaat untuk meningkatkan ketakwaan kepada Allah, SWT dan menjadi orang yang berilmu.

Pendidik dengan karakter yang baik, akan ditiru oleh peserta didik, dan tujuan pembelajaran akan menghasilkan tujuan yang baik. Berikut hasil observasi yang peneliti dapatkan dan disajikan dalam Tabel 4 .

Tabel 4. Hasil Observasi Pelaksanaan Pendidikan Transformatif yang Dilakukan Mahasiswa dalam Menghasilkan Pendidik yang Islami

\begin{tabular}{cc}
\hline Indikator Pendidik yang Islami & Persentase \\
\hline Bertaqwa & $95 \%$ \\
\hline Uswatun Hasanah & $78 \%$ \\
\hline Berilmu & $72 \%$ \\
\hline Sehat Jasmani & $74 \%$ \\
\hline Berkelakuan Baik & $67 \%$ \\
\hline
\end{tabular}

Usaha yang sudah mahasiswa lakukan seperti kegiatan membaca do'a sebelum perkuliahan dimulai, tujuannya agar ilmu yang didapatkan berkah dan bermanfaat. Usaha-usaha yang dilakukan mahasiswa yang belum maksimal perlu diperbaiki dengan cara evaluasi dan mencari solusi, agar nanti terjadi perubahan dengan usaha pengembangan karakter pendidik yang islami.

Dari hasil wawancara hambatan yang dirasakan mahasiswa adalah hambatan dari pengaruh faktor lingkungan. Lingkungan tempat tinggal 
mahasiswa berada tidak mendukung dalam pengembangan karakter islami mahasiswa. Pola interaksi pelajar atau anak muda di lingkungan mahasiswa kebanyakan hidup bebas, tidak patuh pada aturan agama.

Dalam mengatasi hal tersebut perlu kerjasama dengan masyarakat dan orang tua mahasiswa, lingkungan masyarakat berperan penting dalam membudidayakan sikap islami para mahasiswa maupun pelajar dan anak muda di sekitar tempat tinggal mahasiswa. Karakter sesorang muncul dari sebuah kebiasaan yang berulang-ulang dalam waktu yang lama serta adanya teladan dari lingkungan sekitar, pembiasaan itu dapat dilakukan salah satunya dari kebiasaan prilaku keberagaman anak dengan dukungan lingkungan sekolah, masyarakat, dan keluarga (Nur, 2013).

Lingkungan keluarga juga sangat berperan penting dalam membiasakan perilaku yang positif anak, orang tua juga harus menjadi teladan bagi mahasiswa, selanjutnya baru menerapkan paraturanperaturan yang positif, untuk pembiasaan-pembiasan mahasiswa di rumah. Contohnya dalam mengelola waktu, antara membuat tugas dan berinteraksi dengan teman, waktu yang digunakan haruslah bermanfaat dan ada sisi positifnya.

Banyak usaha yang bisa mahasiswa atasi dalam mengendalikan pengaruh buruk pada dirinya, diantaranya banyak mengisi waktu luang dengan mendengarkan ceramah agama, berkumpul dengan orang-orang yang berilmu, membentuk karakter yang islami, memberikan aura positif pada teman yang belum baik akhlaknya, membiasakan hidup disiplin, tanggung jawab, dan lain sebagainya. Kesuksesan seseorang mahasiswa berawal dari sikap dan akhlak yang baik sesuai dengan yang dicontohkan Rasulullah SAW yang merupakan suri tauladan bagi kita umatnya. Melalui konsep pendidikan islam secara pragmatis, seseorang pendidik berusaha semaksimal mungkin membentuk karakter, akhlak, dan perilaku mahasiswa (Muzakkir, 2010).

Selain pengembangan karakter yang islami, usaha lain yang mahasiswa lakukan dalam pelaksanaan pendidikan transformatif adalah pengembangan profesional mahasiswa untuk kesiapan mereka ke lapangan dalam profesi keguruan. Peneliti menyajikan hasil observasi 
terhadap usaha mahasiswa dalam mengembangkan sikap profesionalnya dalam bentuk tabel, berikut peneliti sajikan hasil observasi pada Tabel 5.

Tabel 5. Hasil Observasi Pelaksanaan Pendidikan Transformatif yang Dilakukan Mahasiswa dalam Menghasilkan Pendidik yang Profesional

\begin{tabular}{cc}
\hline Indikator Pendidik yang Islami & Persentase \\
\hline Pedagogik & $74 \%$ \\
\hline Profesional & $70 \%$ \\
\hline Sosial & $78 \%$ \\
\hline Kepriadian & $75 \%$
\end{tabular}

Usaha mahasiswa dalam mengembangkan profesional diri masih belum maksimal pada kompetensi profesional. Jika analogi ke dalam presentase, hanya $70 \%$ pelaksanaan yang sudah diusahakan oleh mahasiswa. Hal ini harus diperbaiki dan sebagai bahan evaluasi bagi mahasiswa dan program studi tadris matematika.

Hasil wawancara yang peneliti peroleh bahwa usaha mahasiswa yang belum maksimal terdapat pada kegiatan memperbanyak ilmu pengetahuan baik dari buku, internet, maupun media masa. Mahasiswa kurang mengisi waktu untuk membaca, mencari sumber-sumber perkuliahan yang baru. Mereka sangat jarang sekali untuk membaca dan mempelajari materi sebelum tatap muka dimulai. Hal ini berdampak pada pelaksanaan perkuliahan yang tidak efektif dan hasil evaluasi yang belum maksimal.

Permasalahan ini bisa diatasi dengan mengembangkan Standar Kompetensi (SK) mahasiswa yang harus dicapai, menekankan kualitas mahasiswa dari pada kuantitas, mengarahkan mahasiswa agar mengikuti seminar dan pelatihan-pelatihan, penegakan disiplin dalam perkuliahan. Sebagaimana yang diungkapkan (Amat, 2009) strategi yang dapat dilakukan untuk pengembangan profesionalisme guru diantaranya (1) pengembangan standar profesional, kompetensi pedagogik, profesional, kepribadian dan sosial; (2) pengujian kompetensi; (3) menekankan kualitas guru daripada kuantitas; (4) evaluasi kompetensi guru secara periodik; dan (5) pengembangan profesionalisme guru dalam jabatan; serta (5) penegakan kode etik. 
Pengembangan pendidik yang kompetitf sudah dilaksanakan mahasiswa, hanya saja usaha mahasiswa masih minim dan belum maksimal. Berikut peneliti sajikan hasil observasi usaha mahasiswa dalam mengembangkan sikap kompetitif dalam bentuk Tabel 6 .

Tabel 6. Hasil Observasi Pelaksanaan Pendidikan Transformatif yang Dilakukan Mahasiswa dalam Menghasilkan Pendidik yang Kompetitif

\begin{tabular}{cc}
\hline Indikator Pendidik yang Islami & Persentase \\
\hline Karya Ilmiah & $72 \%$ \\
\hline Media & $60 \%$ \\
\hline Beasiswa & $77 \%$ \\
\hline
\end{tabular}

Keikutsertaan mahasiswa dalam seleksi penerima beasiswa sudah sangat bagus, ini terbukti dari hasil pengamatan, sebagian besar mahasiswa tadris matematika mendapatkan bantuan uang kuliah dari beasiswa yang jenis-jenisnya berbeda, beasiswa bidik misi, besiswa berprestasi, beasiswa dari Bank Indonesia (BI), beasiswa Badan Amil Zakat Nasional (Baznas). Usaha yang belum maksimal dari Tabel 6 adalah usaha dalam keikutsertaan dalam merancang media pembelajaran. Padahal mahasiswa seharusnya sudah mahir membuat bahan dan media ajar, guna mempersipakan mahasiswa ketika nanti terjun ke lapangan.

Dari hasil wawancara didapatkan, mahasiswa kurang mengasah keterampilan mereka dalam mengembangkan sebuah media pembelajaran, oleh karena hal tersebut mahasiswa enggan dan tidak percaya diri dalam mengikuti ajang-ajang kompetisi. Kurangnya literasi dan pengetahuan mahasiswa terhadap pengembangan bahan ajar juga menjadi salah satu faktor penghambat dalam kemampuan pengembangan media pembelajaran yang dimiliki mahasiswa. Mahasiswa juga punya rasa takut, jika keterampilan pembuatan media ajar yang mereka ciptakan, akan dinilai salah dan jelek oleh segelintir atau sekelompok orang.

Mahasiswa perlu mengasah terus menerus kemampuannya dalam mengembangkan media pembelajaran, dengan melakukan kegiatan latihan atau pelatihan, dengan demikian akan menjadi suatu pembiasaan pada diri mahasiswa dan akan berdampak pada cakapnya mahasiswa dalam menciptakan media pembelajaran. Sejalan dengan yang 
diungkapkan Wita (Wita, 2006), program pengembangan media sebaiknya dilakukan secara berkesinambungan dan rutin. Dengan demikian seluruh mahasiswa calon guru telah memiliki bekal pengetahuan, pengalaman dan keterampilan untuk membuat desain, membuat media berdasarkan desain serta mempertangungjawabkan secara terbuka juga mengaktualisasikan keterampilan membuat/menyusun perangkat pembelajaran.

\section{Hambatan dalam Pelaksanaan Pendidikan Transformatif di Program Studi Tadris Matematika di IAIN Curup dalam Menghasilkan Pendidik Matematika yang Islami, Profesional, dan Kompetitif}

Pendidik yang islami adalah pendidik yang menerapkan nilai-nilai karakter islami dalam kehidupannya. Dari hasil wawancara yang didapatkan salah satu hambatan dalam mencapai pendidik yang Islami adalah lingkungan. Lingkungan sangat berperan penting sekali atas pola interaksi kita, karena manusia makhluk sosial yang perlu berinteraksi dengan sesama. Untuk itu agar dapat menciptakan karakter yang islami harus dimulai dengan lingkungan yang islami sebagai pendukung pencapaian tersebut. Lingkungan sosial memiliki peranan sebagai wahana pendidikan non formal dalam rangka perubahan tata nilai remaja, sebab dengan bergaul, bertegur sapa dan berkomunikasi secara tidak langsung kita dapat berbagi informasi (Berchah, 2010).

Dalam mencapai keprofesionalan mahasiswa masih perlu meningkatkan motivasi mereka untuk terus menambah ilmu pengetahuan, dan berdikusi dengan teman lainnya guna menambah wawasan dan menyelesaikaan masalah yang dihadapi. Subiharto menyatakan bahwa hambatan-hambatan dalam mewujudkan guru profesional: (a) minimnya niat guru untuk menjadi guru yang profesional; (b) kurangnya waktu untuk bertukar pengalaman dengan guru-guru yang lain; (c) kurangnya guru untuk berinovasi; (d) kurangnya fasilitas-fasilitas modern yang menunjang proses belajar mengajar; dan (e) penyebaran guru tidak merata sehingga terjadi penumpukan guru di pusat kota. 
Pendidik yang kompetitif sangat penting dalam menghadapi era global yang serba canggih saat ini dan penuh persaingan. Lapangan pekerjaan sangat minim dibandingkan jumlah pencari kerja. Dunia kerja tidak hanya menuntut nilai yang tinggi dalam menerima karyawan tetapi yang terpenting adalah keterampilan yang dimiliki seseorang.

Mengasah keterampilan seorang pendidik bisa melalui ajang-ajang kompetisi untuk mengevaluasi sampai dimana kemampuannya dan apa kekurangan dari kemampuan yang ia miliki. Hasil wawancara hambatan yang dihadapi pendidik, adalah motivasi dari dalam diri mahasiswa dan kekurangan ilmu pengetahuan yang mahasiswa miliki. Mahasiswa belum membiasakan diri dalam menambah literasi, mahasiswa belum mampu belajar mandiri, lingkungan yang kurang mendukung. Faktor-faktor yang mempengaruhi motivasi berprestasi: (a) tingkah laku dan karakteristik; (b) harapan orang tua; (c) lingkungan; (d) penekanan kemandirian; dan (e) praktik pengasuhan anak.

\section{SIMPULAN}

Berdasarkan penelitian dapat disimpulkan bahwa pelaksanaan pendidikan transformatif dalam mencapai pendidik yang islami, profesional, dan kompetitif yang dilakukan oleh para dosen di program studi tadris matematika sudah terlaksana, namun dalam pelaksanaanya belum maksimal. Hal ini terlihat dari keikutsertaan dosen dalam ajang kompetensi yang masih minim, literasi dan sumber bahan ajar yang digunakan belum maksimal serta kegiatan mengintegrasikan nilai-niai islami dalam perkuliahan hanya dilakukan beberapa dosen.

Minimnya dosen dalam kegiatan ajang kompetensi juga berdampak pada kepercayaan diri para mahasiswa untuk mengikuti ajang perlombaan baik tingkat regional maupun internasional. Literasi dan sumber bahan ajar yang belum maksimal mengakibatkan mahasiswa kurang termotivasi untuk mengembangkan konsep-konsep matematika, sedangkan minimnya kegiatan integrasi nilai-nilai islami menjadikan rendahnya tingkat motivasi mahasiswa dalam menerima pembelajaran serta memahami keterkaitan ilmu agama dan ilmu umum sehingga karakter pribadi tidak terbentuk. 
Hambatan yang ditemukan dosen adalah kurangnya dukungan sarana dan prasarana yang mendukung dalam kegiatan mengembangkan profesional serta motivasi diri.

\section{DAFTAR PUSTAKA}

Amat, J. (2009). Pengembangan Keprofesionalan Guru Secara Berkelanjutan. Kebumen: DIKPORA Kabupaten Kebumen.

Ane, P. (2015). Membangun Kualitas Bangsa dengan Budaya Literasi. Prosiding Seminar Nasional Bulan Bahasa UNIB . Bengkulu.

Berchah, P. (2010). Pengaruh Lingkungan Sosial dan Sikap Remaja Terhadap Perubahan Tata Nilai. LPPM UNILA.

Binti, M. (2015). Implementasi Pendidikan Karakter dalam Pembentukan Kepribadian Holistik Siswa. Jurnal Pendidikan Karakter, 6(1). 90101. Diakses

https://journal.uny.ac.id/index.php/jpka/article/view/8615/7107.

Deden, S. (2018). Meningkatkan Kemampuan Literasi Mahasiswa Menggunakan Google Classroom. Jurnal Pendidikan Bahasa dan Sastra Indonesia. 13(2), 69-78. Diakses di https://journal.uny.ac.id/index.php/jpka/article/view/8615/7107.

Kartasasmita, G. (2004). Peranan Pergurun Tinggi dalam Pembangunan Sumber Daya Manusia. Tasikmalaya: Universitas Siliwangi.

Mujianto, Zubaidi, \& Suprapto, Y. Y. (2012). Peningkatan Kemampuan Menulis Karya Ilmiah Mahasiswa Program Jaringan Telekomunikasi Digital (JDT) Melalui Problem Based Learning (PBL). PS PBSI FKIP Universitas Jember. Jember: PS PBSI FKIP Universitas Jember.

Muzakkir. (2019). Strategi Komunikasi Islam dalam Pembentukan Karakter Insan Kampus. Jurnal Ilmu Komunikasi, 5(1), 1-23. Diakses di http://jurnal.utu.ac.id/jsource/article/view/1115.

Mohammad, K. (2008). Guru dalam Perspektif Islam. Tadris, 3(1), 1-14. Diakses 
Nuqul, F. L. (2005). Pengaruh Lingkungan terhadap Perilaku Manusia. Jurnal Psikologi dan Psikologi Islam, 2(2). Diakses di https://ejournal.uin-malang.ac.id/index.php/psiko/article/view/343.

Nur, A. (2013). Pembentukan Karakter Melalui Pendidikan Agama Islam. Jurnal Al-Ulum (Jurnal Studi-Studi Islam) IAIN Gorontalo, 13(1), 25-38.

Diakses di https://www.journal.iaingorontalo.ac.id/index.php/au/article/view/17 9.

Rinawati, A. (2015). Transformasi Pendidikan Untuk Menghadapi Globalisasi. Ekuitas, Jurnal Pendidikan Ekonomi, 3(1), 93-103. Diakses di https://ejournal.undiksha.ac.id/index.php/EKU/article/view/12783.

Syukron, B. (2016). Implementasi Manajemen Mutu Terpadu (Studi Transformatif pada Perguruan Tinggi). Jurnal Penelitian, 10(2), 231252. Diakses di https://journal.iainkudus.ac.id/index.php/jurnalPenelitian/article/view $/ 1783$.

Taufiq, A. (2018). Paradigma Baru Pendidikan Tinggi dan Makna Kuliah Bagi Mahasiswa. MADANI Jurnal Politik dan Sosial Kemasyarakatan, 10(1). 34-52. Diakses di http://ejurnal.unisda.ac.id/index.php/MADANI/article/view/938.

Wardani, I. (2012). Mengembangkan Profesionalisme Pendidik Guru. Jurnal Pendidikan, 13(1), 32-44. Diakses di http://jurnal.ut.ac.id/index.php/jp/article/view/357.

Wita, S. (2006). Program Pengembangan Media Pembelajaran Sebagai Upaya Peningkatan Keterampilan Calon Guru. Seminar nasional MIPA. Yogyakarta: FMIPA UNY. 
146 | Putri dan Fitmawati: Pelaksanaan Pendidikan Transformatif dalam ... 